\title{
Developing Talent Strategies: Research Based Practice in Oman
}

\author{
Paul Turner, Leeds Business School, UK \\ Alison Glaister, The York Management School, UK \\ Rayya Al Amri, University of Bradford School of Management, UK
}

\begin{abstract}
Organizations struggle to move from the conceptualisation of talent strategies to practical implementation. This paper proposes the use of a talent management evolution matrix which enables the organization to assess and develop the link between the concept and practice of talent management. Gathering data from thirty-nine semi-structured interviews, the matrix is applied in order to understand the differences between the finance and energy sectors in Oman and how they perceive and practice talent management. The findings suggest that Omani talent management practices are shaped strongly by the institutional environment and the nature of business strategy, yet this has resulted in differences between how the finance and energy sectors conceptualize talent management. Despite these differences the findings show that talent management is practiced in similar ways within both the finance and energy sectors, suggesting convergence at the practice level only.
\end{abstract}

\section{Strategy Driven Talent Management}

The achievement of an organization's business goals will require leaders who do the right things, managers who do things right and an engaged workforce that has the skills and capabilities to perform business functions effectively. In short there will need to be alignment between the organization's people and its business strategies. Talent management: "the future proofing of an organization's human capital pool” (Tatoglu et al., 2016: 278), provides a means through which this alignment can be achieved. This paper proposes that a 'talent management evolution matrix' is one way in which an organization can identify its current position alongside a range of strategic options that will facilitate the development of a talent strategy. The paper makes a key contribution to an understanding of how talent management can be evaluated in practice and the matrix connects both the conceptual acceptance of talent management and its implementation. Using empirical evidence gathered through thirty-nine semi-structured interviews this paper examines how the talent management evolution matrix can be applied to organizations in the financial and energy sectors in Oman.

The alignment between business goals and the development of strategic capabilities will be determined by the nature of these goals, the timescales within which they are to be achieved; the geographic footprint over which they are spread and the level of innovation or transformation required. These factors will determine the numbers of people, the level of skills and capabilities and will shape organizational culture. Such a response will lead to people policies and practices that are informed by strategic workforce planning - a comprehensive approach to talent where strategic talent management will be complemented by operational talent activity (Collings et al., 2011). In this respect there is increasing pressure to deliver a talent strategy that is aligned qualitatively (knowledge, skills and behaviours) and quantitatively (return on investment in talent, return on investment in human capital) to business objectives. 
However, talent management strategy is influenced by both internal and external considerations including the structure of the organization and the institutional context within which it resides. Organizational structures might include the creation of global matrices or networks that replace traditional hierarchies and these are shaped by demographic and behavioural changes of a workforce comprising multi-generational, mobile and information 'accessed' workers (Turner and Kalman, 2014). The nature and strength of these internal dynamics will depend upon the markets or sectors in which the organization chooses to compete. External considerations focus on the increasing need for talented people in both knowledge economies and the more traditional sectors. The World Economic Forum (2011) emphasized the need for 'highly educated people' to sustain economic growth and anticipated talent shortages by 2020 in 25 countries, 13 industries and 9 occupational clusters. The universality and diversity of these shortages are striking; ranging from significant shortages of those with supply chain skills at junior, middle and senior management level (Dubey and Gunasekaran, 2015); wide ranging shortages in the five economies of China, Singapore, Thailand, Hong Kong and Taiwan (Tatli et al., 2013); skill shortages in science, technology, engineering and mathematics in the USA (Bayer, 2014) as well as shortages in marketing, construction and health professionals in economies around the world. The effect of labour market forces in both contexts is that the excess demand for leadership, managerial, project, specialist and operational talent highlights the attraction and subsequent retention of this talent.

Thus, internal organizational dynamics and how they combine with and respond to external labour market forces suggests that organizations find it difficult to match the demand for talent with the supply of talent. Even when organizations attempt to do so, they are faced with multiple challenges including the initial identification of talent, the means through which talent can be developed and how to manage this talent resource throughout the organization lifecycle. The alignment objective, clearly laid out in the introduction to this paper, becomes less clear once the objectives for talent management move from conceptualization to operationalization.

\section{Key Constructs of Talent Strategy, Management and Organizational Alignment}

There has been a good deal of research on several of the key constructs of talent strategy and management (Tarique and Schuler, 2010). Guidance on the principles of strategic talent management have been set out (Stahl et al., 2011); and how to mobilize the organization to achieve strategic alignment through talent management and human resource development (HRD) is articulated (Alagaraja, 2013). In addition, research outputs include work on the importance of executive and manager engagement in delivering talent strategy (Anderson, 2009; Bjorkmann et al., 2011); the effectiveness of the tools of talent management (Yarnall, 2011; Scott-Ladd et al., 2010) and some of the measures needed to assess its progress (Yapp, 2009). The differences between twentieth and twenty-first century talent strategy have been noted (Capelli, 2008) and advice exists on how to turn organizations into 'talent factories' (Ready and Conger, 2007) for talent management in a new era (Cheese, 2010). Strategy driven talent management (Silzer and Dowell, 2010) is high on both the HRD and corporate agenda, but the evidence of the effectiveness of strategic alignment is mixed (Gibb and Wallace, 2014), explained in part, by the key challenges that organizations face in operationalising a talent management strategy.

The first challenge — defining the meaning of talent and talent management — arises because of the inconsistent definitions of talent at the national, regional or global level leading to contradictions in advice and fragmentation in theory (Tarique and Schuler, 2010). On the 
one hand, talent management can be defined as "the systematic attraction, identification, development, engagement/retention and deployment of those individuals with high potential who are of particular value to an organization" (Tansley et al., 2007: xi); or in a global context talent management may be considered as the "activities and processes that involve the systematic identification of key positions which differentially contribute to the organization's sustainable competitive advantage, the development of a talent pool of high potential and high performing incumbents to fill these roles, and the development of a differentiated human resource architecture to facilitate filling these positions with competent incumbents and to ensure their continued commitment to the organization" (Collings and Mellahi, 2009: 304-313.) Such definitions depend upon the predominant philosophy of the end user and whether they adopt pools, practice, people or positions in their approach to talent management (Collings and Mellahi, 2009; Scullion and Collings, 2010; Sparrow, Scullion, and Tarique, 2014). These approaches hinge on the idiosyncrasies of the operating environment and the opinions of key stakeholders and decision makers (Zhang and Bright, 2012). Such philosophies place the concept of talent on a continuum ranging from an approach which is exclusive, involving only a few peoplenormally the executive cadre, successors and high potentials, to one that is inclusive where everyone is talented. In a recent study of talent management in multinational companies, Iles et al., (2010) found that the majority adopted an exclusive approach to talent management resulting in integrated and selective human resource management systems. For some, this involved an 'exclusive-people' focus on certain groups of high-performing or high-potential people, whilst for others it meant an 'exclusive-position' focus on certain key positions in the organization. A minority of organizations had an inclusive approach and a few were more organizationally focused moving towards a social capital perspective (Iles et al., 2010).

The challenge facing HRD and talent management professionals is that, in spite of this continuing debate about the meaning of talent and talent management, there is an expectation from the organization's executives that those associated with delivering talent management will add value to the achievement of organization goals. For some, the expectation is to become talent factories (Ready and Conger, 2007), ensuring a continuing supply of people to fill key positions. This will require a dual focus, first a focus on functionality (rigorous talent processes that support strategic and cultural objectives) and second, a focus on vitality (the emotional commitment of managers, reflected in daily actions). Yet, for others, the objective of their talent strategy will be operational - to provide replacements or successors to key positions; to attract and retain graduates; to deliver management and leadership development. Both the importance of talent and its effective management are critical success factors (Vaiman et al., 2012) that will be shaped by an organization's context including the evolution and cultural attributes of the organization and the unique characteristics of the competitive environment.

Therefore, to resolve many of the issues organizations face when developing their talent strategy there is a need to ensure an alignment with their own context. Each organization will have a different starting point from others, as such, a different set of expectations of what is meant by and what is included under the headings of talent strategy and management. Given these differences, organizations will adapt academic insight and practical learning to their own experiences. Despite these differences, strategists and decision makers in the organization need to consider the following issues: how well is talent and talent management understood and supported in the organization? And how effective is the organization at executing talent strategy - i.e. turning the concept into practice? 


\section{A Construct for Assessing the Effectiveness of Talent Management — the Talent Management Evolution Matrix}

Developing a talent strategy and associated talent management activity will be heavily influenced by both the environment in which the organization operates and the position of that organization in respect of its talent management evolution. It will depend on both the definition of talent and the objectives set within the organization for talent management. Once these have been identified then it will be incumbent on those delivering the strategy to ensure coherence between idea, strategy and execution, an alignment critical to success. As we have described above, coherence and consistency in approach are not always in evidence in the field of talent management.

In response to this and to provide a framework against which a talent strategy can be delivered, a talent management evolution matrix was developed in 2014 and 2015 and subsequently used to facilitate discussions about talent strategy in organizations (Turner, 2015: a and b) across the UK, Europe and the Middle East. The matrix is based on the assumption that there are two important sets of criteria in determining the position of an organization in respect of its talent management (and see also Figure 1). The first is the extent to which talent is understood to be an important consideration in the delivery of an organization's strategy and the way in which it manages its people; the level of executive and management knowledge and commitment; and the level of resourcing and workforce engagement. These factors form the basis of the first requirement of the talent management evolution matrix i.e. conceptual acceptance, which became one of two axes on the matrix. include the extent of agreement on the definition of talent, the extent of agreement on the definition and scope of talent management, the roles and responsibilities of senior executives for talent management, and the measures that are used to monitor the process of talent management.

The second is how well an organization delivers, or is resourced to deliver, its talent management programmes and activities. Coherence in delivery means "the balancing of natural internal competition to get there first or to show more benefits than others against the need to make the idea one that is accepted enthusiastically throughout the organization" (Turner and Kalman, 2014: 131). This is referred to in the talent management evolution matrix as practical implementation. Initial dialogue with talent practitioners suggests the need to assess the degree to which talent management and its associated activity are aligned to business goals as well as the level of coordination of actions and policies within and without the talent management function. In addition, there is a need to consider the extent to which talent management roles are delineated and understood amongst people management specialists and their respective organization managers. On this axis, a full suite of well-supported leadership programmes, a wide range of online training options, useful career maps and transparency in opportunity (membership of projects, job moves and so on) would result in a high rating on the scale of practical implementation. Once again, agreement of practical implementation is contextual, will use benchmarking data as 'evidence' and will have the support of executives and managers in its determination.

Within the talent management evolution matrix, individual organizations self-assess their position on the conceptual acceptance scale. HRD and talent management professionals can provide evidence of what takes place in other organizations through their own benchmarking and this can provide some kind of talent context in which the discussion about progress can be made. The important assumption is that the process of establishing conceptual acceptance is 
an inclusive one; that it has the support of executives and managers and there is an element of workforce feedback - possibly through performance management data or employee attitude or climate surveys. Once the terms of reference for the two axes have been agreed, the organization will be able to identify their current position and decide a target point for the future, crafting a talent strategy accordingly. The following narrative shows how the matrix was used to evaluate talent management evolution in organizations operating in the finance and energy sectors in Oman.

\section{Implementation of the Talent Management Evolution Matrix in the Omani Context}

Semi structured interviews were conducted with business executives, line managers, talent management professionals and HR generalists in the Omani finance and energy sectors. Each of the organizations reviewed had well-developed systems of talent management crafted against the idiosyncrasies of Oman's institutional environment.

A particular feature of Oman is its Omanisation policy, a government initiative requiring $90 \%$ of positions to be filled with Omani people, suggesting a greater focus on the attraction, retention and development of talent. Social and cultural pressures, perceived career opportunities and the chance for further investment in skills have resulted in a strong inclination to work in the government (public) sector rather than the private sector (Al-Ali, 2006; Al-Lamki, 1998; Budhwar and Mellahi, 2006). Skill shortages have led to increasing competition amongst organizations and even the finance sector faces tough competition from both the government and new banks in attracting and retaining talented local people. This is aggravated by the inability of higher education institutions to train sufficient graduates to meet current and future demand (Supreme Council for Planning, 2012). In summary, the context for talent and talent management in Oman is a complex one that has heightened the competition for talent and therefore the need for a more a nuanced and strategic approach to talent management.

\section{Conceptual Acceptance and Talent Management in Oman}

The first factor in understanding conceptual acceptance was to identify how organizations in Oman defined talent and whether this definition was accepted and understood organization wide. Our findings show that external, institutional and internal organizational pressures have significant effect on the definition of talent and the shaping of the approach to talent management. Amongst these were government regulation, competition, and the nature of the labour market and the philosophy of the organization.

The effect of these forces on the incidence and the definition of talent was marked. At a macro level, each of these organizations were translating and responding to the Omanisation policy - developing talent management systems to support and increase the employment of a local workforce. On a micro level, those in the finance sector equated talent to those with high potential, an exclusive approach that was people-centred; whilst those in the energy sector regarded talent as those with critical skills - a more role-focused approach and a more inclusive definition of talent management. In the finance sector the exclusive approach focused on the need for leadership skills in response to growing competition. The inclusive approach in the energy sector 
was a response to changing business requirements where the production of oil has moved from the primary to the secondary stage, a complexity that requires a technically skilled workforce.

Conceptual acceptance is also driven by a long-term focus in both sectors and an emphasis on business sustainability. Talent management was increasingly used for succession planning purposes, in order to produce a sufficient pool of competent and knowledgeable employees at different managerial levels. However, business sustainability in operational terms also led to a consideration of broader corporate social responsibilities including a conscious reduction in Oman's unemployment rate, the development of local people who are able to access more stable careers and therefore influence competitiveness at a national level. Thus in Oman, talent management is not only driven by business need but a sense of responsibility to the country as a whole.

The findings indicate that 'talent' is a dynamic concept that is defined according to the internal and external operating pressures of the organization. They also indicate that strong external (political and labour market) pressures have created a demand from organizations for a strategic focus on talent. Therefore, the finance and energy sectors in Oman show a relatively high level of conceptual acceptance of talent management.

\section{Practical Implementation in Talent Management in Oman}

Definitions of talent management shape the operationalisation of talent management practices. Yet, while the broader conceptualizations of talent management differed (more exclusive in the finance sector and more inclusive in the energy sector), in practice, both sectors adopted hybrid approaches through a differentiated talent management architecture that included all Omani workers. Through a range of assessment measures employees were offered a diverse range of training and development opportunities. In this way it was possible to allocate what was perceived as the right 'talent' to the right development opportunity. This is a major consideration when looking at the second axis of the talent management evolution grid i.e. practical implementation. This approach enabled the development of specific talent management practices that were related directly to higher level positions, but other talent management practices focused on all Omani employees (to comply with Omanisation policy), ensuring an effective means through which talent could be deployed to different positions while at the same time adhering to a culture of fairness within the workforce.

In this approach to talent management, the identification stage is critical. This is consistent with other research on the area and is an important stage for ensuring that the right talent is allocated to the right position (McDonnell, 2011). Thus, organizations use different assessments including tests for reasoning ability, interviews, consideration of work experience and qualifications in order to allocate each employee to the right level.

Practices also included:

- Competency frameworks for different layers of the organization.

- Assessment centres using psychometric testing, interviews and case-studies. While it is expected that assessment criteria will differ according to the specific characteristics of the organization, both sectors considered age, nationality, experience and performance, 
highlighting the interplay between government regulation and organizational need.

- Learning and development opportunities for those identified as high potential (exclusivity).

- Training programmes to address the critical skills and abilities of the wider workforce (inclusivity).

- Combining assessment criteria with structured feedback to enhance the employees' skills and place them in the right positions.

- Using coaching and mentoring for both the management and development of talent - most line managers and talented employees in the finance and petroleum sector organizations believed in the importance of coaching and mentoring as an effective way of managing and developing, a point recognized as an important contributor to the effectiveness of talent management (Bjorkman et al., 2011).

- Structured career paths aligned to development plans.

In both the finance and energy sectors, practical implementation (the second axis on the talent management evolution matrix) is relatively high. A wide range of tools and processes were in place and these were effectively implemented. It is evident that the finance and energy sectors understand the importance of talent management in identifying the right person through specific objective criteria rather than through subjective measures. The use of selection and assessment criteria in managing and developing talent suggests that the organizations have a structured scientific approach to identifying and developing talent that shape the development and deployment of a differentiated talent management architecture. The result is the increasing maturity of talent management practices and systems that are able to respond to the needs of both the organization and the country as a whole.

An initial assessment of the position of organizations in the finance and energy sectors in Oman suggests that both have strengths in the areas of conceptual acceptance and practical implementation of talent management:

- In the finance sector, a high level of conceptual acceptance is demonstrated through well- developed systems and processes for the identification of high potential signifying an exclusive approach with an emphasis on resourcing leadership positions. Furthermore, talent management is a critical part of the succession planning process.

- In the energy sector, on the other hand, conceptual acceptance is based on a more inclusive approach to talent management determined largely by the need to resource areas of critical skill driven by changing business requirements. There is recognition in the sector of the need for an effective talent strategy which takes a different perspective to that of dealing with high potentials and succession management processes. In this respect talent management is seen as part of a broader resourcing strategy.

- There is common ground on conceptual acceptance in both sectors, including a long term perspective on the subject of talent; recognition of the strategic value of talent to competitive positioning and an understanding of the economic benefits of talent management such as reducing unemployment and improving the economic sustainability of the economy. 
Both the finance and energy sectors have demonstrated effectiveness in several aspects in practical implementation including:

- There are differentiated talent management architectures to support the particular approach taken by organizations within the sector.

- A wide range of development opportunities tailored to individual positioning.

- The extensive use of tests and structured feedback to enable individual development plans to be put in place.

- A growing emphasis on coaching and mentoring to support the talent management process.

An evaluation of conceptual acceptance and practical implementation in the finance and energy sectors in Oman suggests that both have maturing positions in the former and well-crafted systems and processes in the latter. In this respect there is little difference in their respective placement. Figure 1 shows the possible position of the sectors on the talent management evolution matrix.

Conceptual Acceptance

- Agreed definition of talent throughout the organization.

- Executive level 'buy in' to the concept of talent management.

- Clearly defined objectives for talent initiatives and talent management aligned to business objectives.

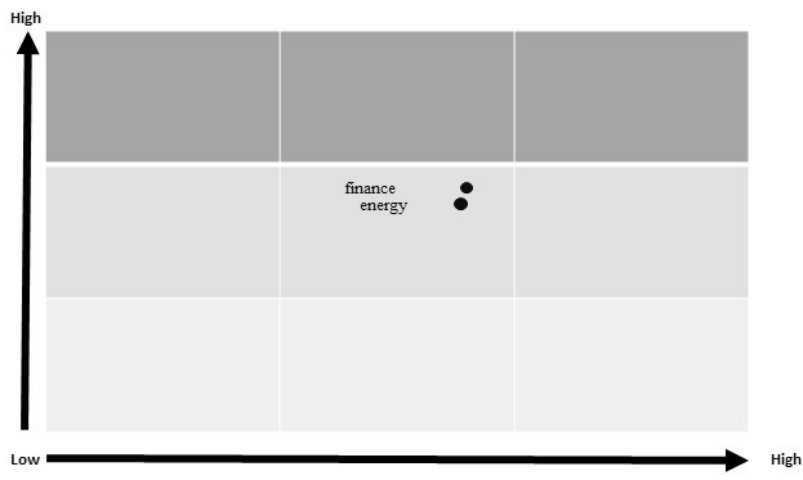

Practical Implementation

- Assessments and measures for talent management in place.

- Well-crafted implementation plans.

- A wide range of 'tools of talent'.

- Talent development aligned to competency frameworks.

Figure 1 The Talent Management Evolution Matrix — organizations in the Finance and Energy Sectors in Oman

\section{Discussion and Conclusion}

This paper proposed that the talent management evolution matrix is one way in which an organization can identify its current position alongside a range of strategic options that will facilitate the development of a talent strategy. The paper makes a key contribution to an understanding of how talent management can be evaluated in practice and the matrix connects 
both the conceptual acceptance of talent management and its practical implementation. Using empirical evidence gathered through thirty-nine semi-structured interviews this paper examined how the talent management evolution matrix can be applied to organizations in the finance and energy sectors in Oman.

The findings highlighted key differences between the sectors, with the finance sector embracing the talent management concept more fully with clear links to a succession management strategy. This was due, in part, to a more exclusive focus on leadership development. Companies in the energy sector, on the other hand, had a less-developed idea about how to incorporate and integrate the talent management concept, which focused predominantly on the skills needs of the business rather than the broader workforce planning issues. However, while there were differences in the extent to which these sectors appeared to conceptualize talent management, there were also similarities. The talent management concept was considered a long-term perspective, responding to the broader context of the organization - a response to competitive positioning and an understanding of the economic benefits made possible through a talent management approach. While an understanding of the talent management concept differed between the two sectors, there was little variation in the practical implementation of talent management and practices were mirrored between the sectors.

There are several implications of these findings for Omani companies. The first is that while talent management as a concept is driven by Oman's institutional environment, organizations should not rely on these pressures to encourage a focus on long-term sustainability in terms of how they consider the concept of talent management and its subsequent practices. Talent management both as a concept and a practice needs to reflect the strategies of the organization and what it considers to be its core competence. Talent management should be embedded within the DNA of the organization regardless of government policy. Second, talent management practices need to be fit for purpose and require configurational alignment between economic exigencies, business strategies and human resource management strategies and practices (of which talent management is a part). It is important to remember that talent management acts as an important signal to all of its stakeholders and is central to the psychological contract (Martin and Cerdin, 2014). Positive signals are imperative if organizations are to manage the expectations of the workforce, capture new talent and foster positive perceptions within the external community. Third, the focus on age as a criterion to define who is considered to be talented is somewhat dangerous and the talent management process needs to address more clearly issues of parity, transparency and equity. Talent management should be considered more than the identification of a younger group of individuals who can progress through key positions and needs to be focused on facilitating and developing knowledge transfer networks within the organization. Finally, the focusing of talent management on Omanis in a bid to reduce the reliance on expatriates is also dangerous as the expatriate workforce is considered to be highly skilled and therefore central to the sustainable competitive advantage of the organization. The exclusion of this group of expatriates from the talent management lifecycle could result in the breakdown of relations and the withholding of vital skills.

From a practice perspective, Omani organizations should consider further investment in multisource assessments that will encourage more diversity and reduce the potential for bias and the use and investment in one's own personal network. Further, organizations should consider a more developed use of coaching and mentoring, both on a formal and informal basis as this will assist the retention of key talents but also foster a more open culture, developing attitudes, behaviours 
and competencies that are aligned to the concept of talent management. Talent managers should engage with educational establishments and foster links encouraging dialogue in the design of new curricula and teaching practice.

By separating the conceptualization of talent management and the operationalization of talent management - the talent management evolution matrix is a valuable tool for HRD and talent management practitioners. It facilitates the talent management logic. First, it enables practitioners to make the connection between how the organization views its competitive positioning, its relationship with the institutional environment and internal and external stakeholders and its core competence. While organizations differ in terms of maturity, size, sector, market, lifecycle, practitioners will also need to be mindful of (and potentially question) the cultural lens through which they are observing each of these factors. Second, it encourages practitioners to consider the practices that can respond to these factors. The talent management evolution matrix transforms a potentially fragmented and opaque exercise into a more strategic, cohesive and transparent management process.

\section{References}

Alagaraja, M. (2013). Mobilizing organizational alignment through strategic human resource development. Human Resource Development International, 16 (1).

Al-Ali, J. (2006). Emiratisation in the local labor force of the UAE: a review of the obstacles and identification of potential strategies, Proceedings of the 20th ANZAM (Australian New Zealand Academy of Management) Conference on "Management: Pragmatism, Philosophy, Priorities", 6-9 December 2006, Central Queensland University, Rockhampton.

Al-Lamki, S. (1998). Barriers to Omanisation in the private sector: the perception of Omani graduates. The International Journal of Human Resource Management, 9 (2), 377-400.

Anderson, V. (2009). Desperately seeking alignment: reflections of senior line managers and HRD executives. Human Resource Development International, 12 (3).

Bayer (2014). The Bayer Facts of Science Education XVI: US STEM Workforce Shortage-Myth or Reality? Fortune 1000 Talent Recruiters on the Debate, Journal of Science Education and Technology, 23 (5), 617-623.

Bjorkman, I., Ehrnrooth, M., Smale, A., and John, S. (2011). The determinants of line management internalisation of HRM practices in MNC subsidiaries, International Journal of Human Resources Management, 22 (8).

Budhwar, P., and Mellahi, K. (2006). Managing human resources in the Middle East. New York: Routledge.

Capelli, P. (2008). Talent Management for the Twenty-first Century, Harvard Business Review, March.

Cheese, P. (2010). Talent management for a new era: what we have learned from the recession and what we need to focus on next ', Human Resource International Digest, 18 (3).

Collings, D. G., and Mellahi, K. (2009). Strategic talent management: A review and research agenda. Human Resource Management Review, 19 (4), 304-313.

Collings, D. G., Scullion, H., and Vaiman, V. (2011). European perspectives on talent management. European Journal of International Management, 5 (5), 453-462.

Dubey, R. and Gunasekaran, A. (2015). Shortage of sustainable supply chain talent: an industrial training framework, Industrial \& Commercial Training, 47 (2).

Gallardo-Gallardo, E., Dries, N. and González-Cruz, T. F. (2013). What is the meaning of 'talent' in the world of work? Human Resource Management Review, 23 (4), 290-300.

Garavan, TN., Carbery, R., and Rock, A. (2012). Mapping talent development: definition, scope and architecture, European Journal of Training and Development, 36 (1).

Gibb, S., and Wallace, M. (2014). Soul mates or odd couples? Alignment theory and HRD, European Journal of Training and Development, 38 (4), 286 - 301 
Illes, P., Chuai, X., and Preece, D. (2010). Talent Management and HRM in Multinational companies in Bejing - definitions, differences and drivers, Journal of World Business, 45 (2).

Martin, G., and Cerdin, J.-L. (2014). Employer branding and career theory: new directions for research In P. Sparrow, H. Scullion and I. Tarique (Eds.), Strategic Talent Management: Contemporary Issues in International Context. Cambridge: Cambridge University Press.

McDonnell, A. (2011). Still fighting the "War for Talent"? bridging the science versus practice gap. Journal of Business and Psychology, 26 (2), 169-173.

Ready, DA. And Conger, JA. (2007). Make your Company a Talent Factory, Harvard Business Review.

Scott-Ladd, B., Travaglione, A., Perryer, C., and Pick, D. (2010). Attracting and retaining talent: Social Organisational support as an emergent concept, Research and Practice in Human Resource Management, 18 (2).

Scullion, H., and Collings, D. (2010). Global Talent Management, Abingdon: Routledge.

Silzer, R., and Dowell, B. E. eds. (2010) Strategy-Driven Talent Management: A Leadership Imperative, Wiley, San Francisco.

Sparrow, P., Scullion, H. and Tarique, I. (eds.) (2014). Strategic Talent Management: Contemporary Issues in International Context, Cambridge: Cambridge University Press.

Stahl, G. K. et al. (2011). Six Principles of Effective Global Talent Management, MIT Sloan Management Review, Winter.

Supreme Council for Planning. (2012). Human Resource Report Oman, Sultanate of Oman: Muscat.

Tansley C., Turner P., Foster C., Harris L., Sempik A., Stewart J., and Williams H. (2007). Talent, Strategy Management and Measurement, CIPD, London.

Tarique, I., and Schuler, R. S. (2010). Global talent management: literature review, integrative framework, and suggestions for further research, Journal of World Business, 45 (2).

Tatli, A., Vassilopoulou, J., and Özbilgin, M. (2013). An unrequited affinity between talent shortages and untapped female potential: The relevance of gender quotas for talent management in high growth potential economies of the Asia Pacific region, International Business Review, 22 (3).

Tatoglu, E., Glaister, A. J., and Demirbag, M. (2016). Talent management motives and practices in an emerging market: A comparison between MNEs and local firms. Journal of World Business, 51 (2), 278-293. doi: http://dx.doi.org/10.1016/j.jwb.2015.11.001.

Thunnissen, M., Boselie., And Fruytier, B. (2013). A review of talent management: 'infancy or adolescence? International Journal of Human Resource Management, 24 (90).

Thunnissen, M., and Arensbergen, V. (2015). A multi-dimensional approach to talent, Personnel Review, 44 (2).

Turner, P. A., and Kalman, D. (2014). Make Your People Before You Make Your Products, Wiley, London.

Turner, P. A. (2015). Building Individual Leadership Plans That Work, Succession Management Summit, Stamford Global, Amsterdam, October.

Turner, P. A. (2015). The Talent Evolution Grid: developing a Talent Strategy for the Networked Age, Middle East HR Summit, Dubai, November

Vaiman, V., Scullion, H. and Collings, D. (2012). Talent management decision making. Management Decision, 50 (5).

World Economic Forum (2011). Global Talent Risks Report, World Economic Forum, Switzerland http:// www3.weforum.org/docs/PS_WEF_GlobalTalentRisk_Report_2011.pdf

Yapp, M. (2009). Measuring the ROI of talent management, Strategic HR Review, 8 (4).

Yarnall, J. (2011). Maximising the effectiveness of talent pools: a review of case study literature, Leadership \& Organization Development Journal, 32 (5).

Zhang, S., and Bright, D. (2012). Talent definition and talent management recognition in Chinese privateowned enterprises, Journal of Chinese Entrepreneurship, 4 (2).

\section{The Authors}

Paul Turner is Professor of Management Practice at Leeds Business School and has held Professorial positions at Universities in Birmingham, Cambridge and Nottingham. He was 
previously President (EMEA), Convergys, Group HR Business Director, Lloyds TSB and Vice President, CIPD. He has held Executive and Non-Executive positions with organizations in Europe, the USA and Asia. Paul has Chaired HR and Talent Conferences throughout the world; was a judge on European and Middle East HR Excellence and CIPD People Management Awards and is the author or co-author of Make Your People Before You Make Your Products (Wiley, 2014), Workforce Planning (CIPD, 2010), The Admirable Company (Profile, 2008), TalentStrategy, Management and Measurement (CIPD, 2007), Organisational Communication (CIPD, 2003) and HR Forecasting and Planning (CIPD, 2002). He has written articles for business and academic journals and the International Press.

Dr Alison J. Glaister is Lecturer in Strategic Human Resource Management at The York Management School, University of York. She has previously held lectureships at Bradford University School of Management and Aston Business School. Alison's research focuses on international HRM and includes the conceptualisation and operationalisation of talent management strategies and the impact of outsourcing and organizational networks on the role of HR and the employees they serve. She has published in the Journal of World Business, Human Resource Management Journal, Management International Review and International Journal of Human Resource Management.

Rayya Al-Amri is a PhD student at the School of Management, University of Bradford; Rayya's research focuses on exploring talent management phenomenon in the developing country. She has also been a senior lecturer in HRM at the Higher College of Technology in the Sultanate of Oman since 2006. Rayya has presented papers on Talent Management in international conferences in UK and Europe; e.g. third TM workshop in Berlin 2014, fourth TM workshop in Spain, and BAM conference 2015, UK. 